\title{
Pre-service English Teachers' Perceptions Towards Grammar Translation Method for Teaching English in High School
}

\section{Persepsi Guru KPL Bahasa Inggris dalam Penggunaan Metode Grammar Translation untuk Mengajar Bahasa Inggris di Sekolah Menengah}

\author{
Rosa Dianovita Sari, Utami Widiati*, Siti Muniroh \\ Universitas Negeri Malang, Jl. Semarang No. 5 Malang, Jawa Timur, Indonesia \\ *Penulis korespondensi, Surel: utami.widiati.fs@um.ac.id
}

Paper received: 28-09-2021; revised: 28-11-2021; accepted: 21-12-2021

\begin{abstract}
The Grammar Translation Method (GTM) is an effective classical method for teaching English as a foreign language (EFL) in Indonesia since it makes students understand better that leads them to have better learning outcomes. However, limited information is found regarding the practice of GTM done by the pre-service teachers (PET). Most of the research on GTM focused on the benefits of this method when an in-service English teacher is utilizing this method. Therefore, this mixed-method study aimed to investigate how PET from Universitas Negeri Malang perceived GTM for teaching EFL during their internship. To enrich this study, the researcher also explored PET opinions about students' attitudes toward GTM, and how effective the method is to assist the students in EFL learning. This study discovered that the majority of the respondents believed that the GTM was considered useful in helping PET in improving students' English skills. This is also supported by the positive response of students since they felt more comfortable while learning. Although, GTM has a shortcoming in terms of student-teacher interactions, thus this study recommends that PET should combine GTM and with other methods to make the learning process more effective and in line with the Curriculum 2013 regulations.
\end{abstract}

Keywords: the Grammar Translation Method, pre-service English teacher, perception.

\begin{abstract}
Abstrak
Grammar Translation Method (GTM) merupakan metode klasik yang efektif untuk pengajaran bahasa Inggris sebagai bahasa asing (EFL) di Indonesia karena mampu mempermudah pemahaman siswa yang membuat mereka memiliki pencapaian yang lebih baik. Namun, hanya terdapat sedikit informasi mengenai praktik GTM yang dilakukan oleh para calon guru ahasa Inggris (PET). Sebagian besar penelitian tentang GTM hanya berfokus pada manfaat metode ini ketika guru Bahasa Inggris dalam jabatan menggunakan metode ini. Oleh karena itu, Penelitian metode campuran ini bertujuan untuk mengetahui bagaimana cara pandang PET dari Universitas Negeri Malang terhadap GTM sebagai metode pengajaran EFL kepada siswa sekolah menengah selama kegiatan magang mereka. Untuk memperkaya hasil penelitian ini, peneliti juga menggali pendapat PET tentang respon siswa terhadap GTM, serta seberapa efektif metode ini untuk membantu siswa sekolah menengah dalam pembelajaran EFL. Studi ini menemukan bahwa mayoritas PET menganggap bahwa GTM berguna dalam membantu PET untuk meningkatkan kemampuan bahasa Inggris siswa. Hal ini juga didukung oleh respon positif siswa karena mereka merasa lebih nyaman saat belajar. Meskipun demikian, GTM memiliki kekurangan dalam hal interaksi siswa dan guru, oleh karena itu penelitian ini merekomendasikan agar PET menggabungkan GTM dengan metode-metode terbaru agar proses pembelajaran lebih efektif dan sejalan dengan peraturan Kurikulum 2013.
\end{abstract}

Kata Kunci: metode Grammar Translation, calon guru bahasa Inggris, persepsi. 


\section{Introduction}

Teachers in Indonesia have implemented many interesting teaching methods so that students can effectively learn English. From several existing methods, there is a method that seems very popular among English teachers in Indonesia, namely the Grammar Translation Method (GTM). GTM is a traditional method that was first known as the Prussian Method in the United States. Johann Seidenstucker, Karl Plotz, and H.S. Ollendorf later developed this approach, which became known as the GTM (Mijan, 2018). GTM focused on detailed explanation of grammar since it is a set of principles for constructing sentences, memorizing vocabulary by using vocabulary lists, using declination and conjunctions, and writing activities (Brown, 2015). Furthermore, GTM emphasized translating drills to translate unconnected phrases from the target language to the mother tongue, and since the mother tongue is still employed in GTM, students can develop their high-level reading skills (Brown, 2015). However, since the text is being used as a grammatical analysis exercise, little attention is paid to the content and pronunciation (Brown, 2015).

Despite being a traditional method, GTM is considered a method that is often used by EFL teachers in Indonesia. Suprijadi (2014) found that the GTM is widely used in senior high schools in Bandung, for about 58.82\% of the teachers used GTM. In another region of Indonesia, Elmayantie (2015) also found that the English teachers in SMP Negeri 1 Palangka Raya still used GTM for teaching. Moreover, another method that is widely used for teaching English for elementary students is GTM and Direct Method, as reported by Anabokay and Suryasa (2019), who conducted a study involving EFL teachers of elementary schools in Indonesia.

There are some reasons why EFL teachers in Indonesia are fond of using GTM. Among others, GTM helps teachers to make students have a better understanding of the material, especially if students still lack in English. This method is appropriate for use when students have a basic English level so they can understand the lesson better (Liu, 2019). It also can be used successfully if the teachers employ the appropriate assistant resources that allow teachers to resolve the GTM's limitations (Liu, 2019).

Furthermore, employing GTM can provide teachers with various benefits. According to Khan and Manshoor (2016), students can understand abstract words or terms better, as well as complicated sentences. Furthermore, students are aware of grammatical rules so that they can comprehend content while reading a text and also write grammatically correct sentences, allowing them to examine and solve problems (Khan and Manshoor, 2016). Khan and Manshoor (2016) go on to claim that GTM is beneficial to teachers since it requires less work from the teacher, making it easier for teachers who do not speak English fluently to improve their teaching and save time.

From this, we can see that GTM focuses on accuracy and is taught in the student's mother tongue to improve comprehension (Prastyo, 2015). Therefore, this method is often known to be an effective approach for making students understand the content of a text because the text is translated into the mother tongue. GTM also has a significant impact on students' reading results. This is in line with Afiah's (2014) finding who discovered that the GTM can help students improve their reading skills. Afiah's findings reveal that students' test scores improve from pre-test (60) to post-test 1 (80) and continue to rise to 95 in post-test 2 . This strategy can help students in improving their reading skills. She also mentioned that utilizing GTM can make students feel more challenged and encourage them to try reading more challenging texts along 
with motivating them to read more frequently. Besides helping in reading, GTM is also helping to improve students' writing abilities since reading and writing are the major focus of this method (Richards \& Rodgers, 2002). This is compatible with recent research conducted by Maru'ao (2018) who argued that GTM helps in the development of student's writing skills by allowing them to produce brief paragraphs.

Furthermore, based on the researcher's experience in using GTM during the teaching practicum or KPL program as a pre-service teacher, the researcher also realized that the secondary school student's level of English is still low. This is supported by a study by Dezmalina and Septiani (2018), who discovered that many junior high school students in English class performed poorly in terms of vocabulary, pronunciation, and grammar. Students were confused when the researcher used only English during the learning process, causing them to lose focus of what they were learning at the time. Looking at the students' attitudes, the researcher chose to use GTM. After applying this method, there was a significant change felt by the researcher. This significant change has also been proven by several researchers who have examined directly into a class. Chang (2011) found that the experimental group taught using GTM showed a higher score than the control group which was not taught using GTM. For that, the researcher realized that students had better scores because they understood the material well.

The process of learning became smoother and effective because the students were more communicative with the researcher who was teaching. The reason why they became more communicative than before was that they can understand what the researcher was saying during the learning process. Students also became easier to talk to as they used their mother tongue to communicate with each other in class (Khan \& Mansoor, 2016) that led students to have better motivation in learning. Guerra (2014) claimed that students have a good attitude about the use of translation because it increased their desire to learn English and their comprehension level. This is in line with Mart (2013) who also stated that the use of translation in English learning had a significant impact because it made learning activities more meaningful and the learning process more clear that allowed students to master English.

The GTM Method also can boost students' confidence since this method can make students answer questions correctly both in oral and written exams (Aqel, 2013). The students were not ashamed to ask questions because the researcher did not pressure them to use English in asking questions. They had more courage in asking questions after previously only choosing to be silent during the learning process rather than asking a question in English. Besides, GTM was also very helpful for the researcher in making daily assignments because teachers would find it easier to teach using GTM since the assessment was very objective so that it was easier for teachers to teach or create a challenge for students (Brown, 2015).

Despite its many benefits, GTM has several limitations that should never be ignored (Khan \& Mansoor, 2016), including the fact that it is still teacher-centered and it reverses the language learning process, which should begin with listening but instead begins with reading. Also, some sentences cannot be translated exactly from one language to another. It proved that there is no such thing as a perfect method since each method has its own set of benefits and drawbacks (Syuhudi, 2016). As a result, combining GTM with the recent approaches for enhancing students' creativity and critical thinking abilities is highly suggested. 
As may be seen, the benefits of GTM are widely recognized in the research literature. However, limited information is found regarding the practice of GTM done by the pre-service teachers. Most of the research on GTM focused on the benefits of this method when an inservice English teacher is utilizing this method. Therefore, this study is conducted to investigate how pre-service English teachers of the 2017 batch (PET2017) from Universitas Negeri Malang perceived GTM for teaching EFL to secondary school students during their teaching internship. To enrich this study, the researcher also explored PET2017s opinions about students' attitudes toward GTM, and how effective is the method to be applied to assist secondary school students in EFL learning.

\section{Methods}

The researcher employed a mixed-methods design; explanatory sequences where the data was gathered using questionnaires and interviews, which were conducted in stages (Creswell \& Clark, 2011). By combining the two types of data, the result became more comprehensive, valid, reliable, and objective, making it easier to meet the research's objectives (Sugiyono, 2016). The subject studied in this research is the pre-service English teachers of the 2017 batch (PET2017) from Universitas Negeri Malang since they have completed their teaching internship and they have taken the TEFL course in which they learned various teaching methods.

The researcher decided to collect $60 \%$, or 70 respondents, out of 116 PET2017 respondents, using the Quota sampling process (Arikunto, 2010), in which the researcher collects data from samples with specific characteristics until the desired number of quotas is reached. Meanwhile, for the interview, the researcher employed criterion sampling (Arikunto, 2010), in which she selects 11 questionnaires' respondents who met the criteria determined by the researcher.

The research procedure started with developing both the questionnaire and the interview questions. The questionnaire was adapted based on the questionnaire from a journal by Resmini (2019) and a journal by Payne and Contreras (2019) because the statements listed from both journal articles were related to the topic of this research which explained how big the role of the GTM in the learning process. The researcher selected several examples of relevant questions and then adjusted the subject to match the research topic so the questionnaire can be used as an instrument to gather data to answer the research questions in this study. The questionnaire consisted of 17 statements with four answer options, namely strongly agree, agree, disagree, and strongly disagree. This online questionnaire later will be distributed online through the WhatsApp group which contains all of the ELT students from the 2017 batch and also private chats.

Meanwhile, the interview questions were adapted from a journal by Anabokay and Suryasa (2019) that was related to the information needed for this research. The adaptation of the interview questions began with sorting out the appropriate questions and then adjusting them to the subject. The interviews were carried out online via WhatsApp call. Interviews were conducted after obtaining the approval of willingness to attend interviews on WhatsApp calls from the respondents. The researcher asked 10 questions related to the topic for a depth of knowledge about their perceptions in using the GTM during the learning process.

Both instruments have been validated by two expert validators with the help of validation sheets that have been prepared by the researcher. Following that, the researcher 
plotted the questionnaire with several PET2016 that had almost the same characteristics as PET2017 to ensure that it was ready to be distributed.

The researcher then began to gather the necessary data. First, the researcher distributed the google form questionnaire via WhatsApp. The data was then compiled in Excel and analyzed in SPSS to determine the percentage of each question. Next, it was converted into tables that explained the overall total of each choice selected in each question. Following the completion of the data collection process through the questionnaire, the researcher conducted interviews with 11 respondents who met the given criteria to obtain deeper information about this topic. The data were then transcribed and analyzed using narrative analysis.

The researcher interpreted the results of the questionnaire with the help of additional information obtained from the interviews. The outcomes of the data analysis can be used to answer the research objectives.

\section{Findings and Discussions}

This section contains the result of the data analysis that was collected through the questionnaire, which includes the data's interpretation, which is supported by the results of interviews conducted to obtain more in-depth information for research purposes. The information in this section is intended to answer the objectives.

\subsection{The English Pre-service Teachers' Attitudes Toward the GTM.}

To begin, the researcher analyzed the PET2017 Attitudes towards GTM. According to the questionnaire results, $74.3 \%$ or 52 of the respondents agreed that they had fully learned about GTM in the previous semester. After that, followed by the second-highest percentage, $20 \%$ or 14 of them strongly agreed with the statement. The rest, on the other hand, decided to disagree with the first statement. However, this showed that the majority of English Pre-service Teachers from class 2017 were already familiar with the GTM.

Next, $64.3 \%$ or 45 respondents were strongly agreeing that they used GTM during the KPL program. Along with it, $5.7 \%$ or 4 of them were agreeing with the statement. In contrast, only one person, or $1.4 \%$ was not aware if he was using GTM. This showed how often GTM was used by PET2017. Moreover, $60 \%$ or 42 of them firmly believe that GTM was more comfortable to be used for teaching EFL. Only $1.4 \%$ or only one person chose the opposite. It showed that almost all of the PET2017 were more comfortable using GTM in teaching EFL for secondary school students. See Table 1.

GTM is often recognized as a primary method to use in teaching EFL language (Khan \& Mansoor, 2016). As a result, GTM is considered to be a well-known method to be used during the English learning process in Indonesia. Based on the results of the questionnaire, many PET2017 utilized GTM throughout their internships since it was a convenient method to use. This is supported by the findings of interviews, which revealed that all PET2017 participants felt comfortable while using GTM because it made the learning process more efficient. One of the respondents, respondent 5, said that using GTM helped her deliver the lesson better. Then, according to respondent 8, employing GTM can boost their confidence when teaching. Other respondents, respondents 2 and 9, mentioned that speaking using both languages helps student-teacher interaction since misunderstandings rarely happen. Moreover, all of the interviewees agreed that GTM can help students understand better since students' English 
levels were mostly still low. This proved that both parties felt more at ease when they used GTM since PET2017 can teach effectively and students understand the lesson better. This finding was in line with Eggleston (1977) who stated that teacher decision-making involves fine judgments of the students' levels, the determinations of their needs, and their evaluation of their achievements. Ur (2013) further asserted that the nature of the learner, stakeholder demands, future examinations or assessment procedures, and individual teachers' preferences, strengths, and weaknesses all play a role in teacher decisions.

Table 1. The Results of Pre-Service English Teacher 2017 Attitudes Toward GTM

\begin{tabular}{lcccccccc}
\hline \multicolumn{1}{c}{ Statements } & SA & $\%$ & A & $\%$ & D & $\%$ & SD & $\%$ \\
\hline 1. I have fully learned about the GTM. & 14 & $20 \%$ & 52 & $74.3 \%$ & 4 & $5.7 \%$ & 0 & $0 \%$ \\
\hline $\begin{array}{l}\text { 2. I am aware that I am using the GTM } \\
\text { while teaching English as a foreign } \\
\text { language for secondary school }\end{array}$ & 20 & $28.6 \%$ & 45 & $64.3 \%$ & 4 & $5.7 \%$ & 1 & $1.4 \%$ \\
$\quad$ & & & & & & & & \\
\hline students. & 42 & $60 \%$ & 27 & $38.6 \%$ & 0 & $0 \%$ & 1 & $1.4 \%$ \\
\hline $\begin{array}{l}\text { 4. I feel more comfortable using GTM } \\
\text { while teaching English as a foreign } \\
\text { language. }\end{array}$ & & & & & & & \\
\hline *SA: Strongly Agree; A: Agree; D: Disagree; SD: Strongly Disagree & & & & &
\end{tabular}

\subsection{The English Pre-service Teachers' Opinion About Students' Attitudes Toward the GTM.}

\subsubsection{The English Pre-service Teachers' Opinion About Students' Responses.}

The next statement revealed how the students' response if the teacher used only English in teaching. $55.7 \%$ or 39 of them strongly agreed that students tend to lose their focus if the teacher were using only English in explaining the lesson. The percentage strongly agreed was then followed by $42.9 \%$ or 30 of them who agreed with this statement. On the other hand, only $1.4 \%$ or one person strongly disagreed with this statement. It showed that almost all of the PET2017 agreed that the students tend to lose focus if the teacher used full English, therefore they should use the GTM.

Then, $88.6 \%$ or 62 respondents disagreed or even strongly disagreed with the statement that stated the teacher's habit of using a mixed language in teaching English made students become less confident in their speaking ability. Only $11.4 \%$ or 8 respondents stated otherwise. According to the findings, it can be seen that the use of mixed language hardly affects the students' confidence level in speaking English in the classroom. Supporting the previous statement, $98.6 \%$ of the respondents agreed or even strongly agreed that by using GTM, students became more confident in expressing their ideas in an English class. Meanwhile, only $1.4 \%$ or one respondent stated otherwise. It can be said that employing bahasa Indonesia in this activity had a significant impact on students' confidence during the lesson.

Furthermore, almost all of the PET2017 agreed that students appeared to be more active during the learning process, according to $98.6 \%$ or 69 of the PET2017 respondents. Students also felt more motivated during the learning process. $47.1 \%$ or 33 and $48.6 \%$ or 34 respondents agreed on the statement which stated that students felt more motivated in learning if the teacher used mixed languages. And only $4.3 \%$ or 3 respondents chose the disagree option. It showed that most of the students had a high motivation when the teacher used GTM during their learning process. See Table 2. 
Table 2. The Results of Pre-Service English Teacher 2017 Opinions about Students' Responses

\begin{tabular}{|c|c|c|c|c|c|c|c|c|}
\hline Statements & SA & $\%$ & $\mathrm{~A}$ & $\%$ & $\mathrm{D}$ & $\%$ & SD & $\%$ \\
\hline $\begin{array}{l}\text { 4. I feel like if I explain the lesson in } 100 \% \\
\text { English, the students tend to lose focus } \\
\text { on the subject. }\end{array}$ & 39 & $55.7 \%$ & 30 & $42.9 \%$ & 0 & $0 \%$ & 1 & $1.4 \%$ \\
\hline $\begin{array}{l}\text { 5. The teacher's habit of using a mixed } \\
\text { language in teaching makes students } \\
\text { feel less confident in speaking English. }\end{array}$ & 1 & $1.4 \%$ & 7 & $10 \%$ & 51 & $72.9 \%$ & 11 & $15.7 \%$ \\
\hline $\begin{array}{l}\text { 6. The students become more confident } \\
\text { when using bahasa Indonesia to } \\
\text { express their ideas or raise questions } \\
\text { in class. }\end{array}$ & 34 & $48.6 \%$ & 35 & $50 \%$ & 1 & $1.4 \%$ & 0 & $0 \%$ \\
\hline $\begin{array}{l}\text { 7. The students participated actively } \\
\text { during the lesson when the teacher } \\
\text { used GTM in teaching English as a } \\
\text { foreign language. }\end{array}$ & 29 & $41.5 \%$ & 40 & $57.1 \%$ & 1 & $1.4 \%$ & 0 & $0 \%$ \\
\hline $\begin{array}{l}\text { 8. The students feel more motivated in } \\
\text { learning English as a foreign language } \\
\text { if the teacher used the GTM. }\end{array}$ & 33 & $47.1 \%$ & 34 & $48.6 \%$ & 3 & $4.3 \%$ & 0 & $0 \%$ \\
\hline
\end{tabular}

*SA: Strongly Agree; A: Agree; D: Disagree; SD: Strongly Disagree

Students' interests had an impact on how focused they were in class. As a result, student interest was a crucial factor in motivating them to pay attention and enjoy a class activity (Slameto, 2010). One of the respondents, respondent 7, claimed that when he utilized GTM to explain the material, the students became more engaged in studying English. He stated that students were more interested in studying English since the lessons were more enjoyable as they understood what the teacher said in front of the class. Then, respondent 1 mentioned that GTM helped her in capturing students' attention because students seemed to pay more attention when she used GTM. Respondent 6 further stated that students tended to lose focus and frequently ignored the lecture if a teacher only used English in front of the class. This proved that using GTM can help students become more focused for long periods.

GTM also boosted students' confidence during the lesson since they can raise their ideas using their language. Ozfidan (2017) stated that speaking using mother tongue in school can increase self-confidence. In line with this, respondent 8 stated that students were braver to raise their ideas when she was using both languages rather than only English. Next, respondents 2 and 6 also stated that students became more confident in voicing their ideas and answering some questions during the lesson if they used both languages. From this, we can conclude that using both languages can make the students gain more confidence in their English skills. As a result of this, students will become more receptive during the learning process.

It was also revealed by respondent 7 who said students were more enthusiastic when she utilized GTM. He claimed that students became more comfortable talking with him. This showed that students were more likely to participate actively in the learning process if they can communicate in both languages rather than just English. Another respondent, respondent 4 , also stated that the students seemed more comfortable and can follow the explanation well. It showed that students were not burdened by the lesson if PET2017 utilized GTM. This method can make students feel that they can participate willingly without being forced to do so. As a 
result, the students felt more at ease during the class, making it easier for them to follow the lesson. This was in line with Siregar (2018) who stated that the use of GTM can lead the students to be more responsive during the lesson.

Students' motivations in learning English increased as they got a better understanding of the lesson. It was proven by respondent 3 who claimed that GTM made the students understand better and became more motivated during the learning activity since the teacher was not scolding them harshly if their English was not perfect. Regarding this statement, it was believed that students were more motivated to learn English because they understood the lesson better, and PET2017 was aware that students were still learning English to improve their skills. If the teacher only used the target language to deliver the lesson, it can cause mental inconvenience to the students since there will be a lack of understanding, and English will become a phobia for them (Khan \& Mansoor, 2016).

\subsubsection{The English Pre-service Teachers' Opinion About Students' Achievements.}

All of the PET2017 agreed that students understood better when the teacher explained English material using GTM. A total of $70 \%$ or 49 people strongly agreed and $30 \%$ or 21 people chose to agree with the statement. In line with the previous statement, $60 \%$ or 42 and $40 \%$ or 28 respondents strongly agreed and agreed that students had a better comprehension if the teacher used GTM when teaching reading. We discovered that using a mother language in the classroom had a significant role in a student's English learning.

Furthermore, there were $94.3 \%$ or 66 respondents that agreed or even strongly agreed with the statement which stated that students had better scores if the teacher used GTM. Meanwhile, only $5.7 \%$ or 4 respondents stated otherwise. This showed the efficiency of GTM in the classroom. See Table 3.

Table 3. The Results of Pre-Service English Teacher 2017 Opinions about Students' Achievements

\begin{tabular}{llccccccc}
\hline Statements & SA & $\%$ & A & $\%$ & D & $\%$ & SD & $\%$ \\
\hline 9. & 49 & $70 \%$ & 21 & $30 \%$ & 0 & $0 \%$ & 0 & $0 \%$ \\
$\begin{array}{l}\text { The students had a better } \\
\text { understanding when I explained the } \\
\text { material using the GTM. }\end{array}$ & & & & & & & \\
\hline $\begin{array}{l}\text { 10. } \\
\text { The students had better reading } \\
\text { comprehension when I used the } \\
\text { GTM. }\end{array}$ & 42 & $60 \%$ & 28 & $40 \%$ & 0 & $0 \%$ & 0 & $0 \%$ \\
& & & & & & & \\
\hline $\begin{array}{l}\text { 11. } \\
\text { The students have better scores } \\
\text { when teachers are implementing } \\
\text { the GTM. }\end{array}$ & 13 & $18.6 \%$ & 53 & $75.7 \%$ & 4 & $5.7 \%$ & 0 & $0 \%$ \\
*SA: Strongly Agree; A: Agree; D: Disagree; SD: Strongly Disagree & & & & & & \\
\hline
\end{tabular}

*SA: Strongly Agree; A: Agree; D: Disagree; SD: Strongly Disagree

The finding showed that GTM was effective to improve students' achievement, especially in their reading skills. Respondent 6 claimed that students' reading skills were improved since students understand the content of the text. Then, the other, respondent 3 , also had the same opinion, she reported that students' reading skills were also developed well if the teacher used GTM. This revealed that when students understood the meaning of a reading text, they became more engaged in the content of the reading, leading to a greater willingness to pay attention to the lesson to improve their reading skills. In line with this, Kurniawan (2020) argued in his recent study that teaching reading using GTM was more effective in enhancing students' reading comprehension than teaching reading without GTM. Students' reading comprehension 
improved as a result of their understanding of the reading material as a whole, making it easier for students to understand questions provided by the teacher in a reading activity.

Furthermore, three of the PET2017, in interviews, claimed that GTM also enhanced students' vocabulary. Vocabulary is an important component of reading comprehension (Pan, 2017), therefore, the improvement of students' reading ability must be followed by their vocabulary knowledge. If students had limited knowledge about vocabulary, then it will be more difficult for the students to comprehend a text (Silva \& Cain, 2014). Based on the PET2017 interview, respondent 10 used a vocabulary list in a reading text, which is a characteristic of teaching vocabulary with the GTM (Setiyadi, 2020) because it was simple and easy to memorize. It showed that teaching vocabulary through GTM is thought to be very beneficial in that it allows the teacher to introduce a load of new words to students in a simple way, allowing the students to enhance their vocabulary.

Then, it was discovered that using GTM to explain the foreign terms mentioned by the teacher during the lesson made it easier for students to learn the grammar. Respondent 6 stated that GTM helped students to get used to learning grammar. Another respondent, respondent 10, mentioned that GTM made students aware of the teacher's correction since the teacher corrected them in a language they understand. Debata (2013) argued that grammar will assist students in correcting errors and improving their written work. It showed that by mastering grammar, students will be greatly helped in the process of improving their writing skills since they will have a better understanding of the grammar rules that they must employ in a sentence as well as the various tenses they can use in a text. This of course will lead students to be capable of writing a good simple text. Respondent 3 even stated in the interview that after teaching with GTM, her students had improved their ability to write so that they can write a short text well.

All of the benefits of GTM had resulted in increased students' accomplishments because their level of understanding was improved along with their scores. Students' achievement improved when the teacher used GTM since they were more eager to learn English, according to Respondent 9. Respondents 2 and 5 also reported that after using GTM, students had improved their scores. This highlighted the value of GTM in terms of student achievement.

\subsection{The English Pre-service Teachers' Perceptions About the Effectiveness of the GTM.}

A total of $68.6 \%$ or 48 respondents were agreeing that they can maximize their time in teaching if they were using GTM, even $20 \%$ or 14 respondents were strongly agreeing with this statement. Then the rest, $11.4 \%$ or 8 respondents disagreed with the statement. This revealed that GTM is still relevant and we can still utilize it nowadays. Following that, most of the PET2017 were agreed that GTM is still appropriate to use in Indonesian education. As can be seen, respondents who chose to agree and strongly agree on this statement dominated the proportion, with $68.6 \%$ or 48 respondents choosing to agree and $25.7 \%$ or 18 respondents strongly agreeing. Furthermore, $5.7 \%$ of respondents, or 4 respondents, chose the disagree option. This indicated that, although being a classic method, the majority of the respondents still agreed that this method was still appropriate for use in Indonesia.

Next, $65.7 \%$ or 46 respondents indicated that they want to use GTM for their students when they become teachers in the future. This was followed by $27.2 \%$ or 19 respondents, who responded that they were very interested in employing GTM to teach their future students. 
Meanwhile, $7.1 \%$ of respondents, or 5 people, said they would not use this method in the future. From this, we can see PET2017's enthusiasm to use this method in the future after examining the advantages and disadvantages of the GTM that they experienced through their internship programs.

Moreover, $94.3 \%$ or 66 of respondents chose to Agree and Strongly Agree with the statement that stated GTM gave them lots of advantages. Meanwhile, only $5.7 \%$ of respondents, or 4 out of 70 , disagreed with this statement. With this percentage comparison, we can conclude that, rather than being a negative impact, this method has been shown to have benefits that can lead students in a positive way. In line with the previous statements, $71.4 \%$ or 50 of the respondents decided to agree with the statement that they would recommend the GTM to somebody who will teach English in Indonesia. Then followed by the percentage of respondents who strongly agreed, which is $22.9 \%$ or 16 respondents. The disagreement choice had the least number, at $5.7 \%$ or 4 respondents. This revealed how, after evaluating the effectiveness of the GTM, PET2017 placed a high consideration in using GTM.

Table 4. The Results of Pre-Service English Teacher 2017 Perceptions about the Effectiveness of the GTM

\begin{tabular}{|c|c|c|c|c|c|c|c|c|}
\hline Statements & SA & $\%$ & $\mathrm{~A}$ & $\%$ & $\mathrm{D}$ & $\%$ & SD & $\%$ \\
\hline $\begin{array}{l}\text { 12. I can maximize my time in } \\
\text { teaching and learning using the } \\
\text { GTM. }\end{array}$ & 14 & $20 \%$ & 48 & $68.6 \%$ & 8 & $11.4 \%$ & 0 & $0 \%$ \\
\hline $\begin{array}{l}\text { 13. I think that the GTM is an } \\
\text { appropriate method to be } \\
\text { implemented in Indonesia. }\end{array}$ & 18 & $25.7 \%$ & 48 & $68.6 \%$ & 4 & $5.7 \%$ & 0 & $0 \%$ \\
\hline $\begin{array}{l}\text { 14. I want to teach my future students } \\
\text { using the GTM. }\end{array}$ & 19 & $27.2 \%$ & 46 & $65.7 \%$ & 5 & $7.1 \%$ & 0 & $0 \%$ \\
\hline $\begin{array}{l}\text { 15. I got so many advantages when I } \\
\text { am using the GTM in a classroom. }\end{array}$ & 14 & $20 \%$ & 52 & $74.3 \%$ & 4 & $5.7 \%$ & 0 & $0 \%$ \\
\hline $\begin{array}{l}\text { 16. I recommend the GTM for teaching } \\
\text { English in Indonesia. }\end{array}$ & 16 & $22.9 \%$ & 50 & $71.4 \%$ & 4 & $5.7 \%$ & 0 & $0 \%$ \\
\hline $\begin{array}{l}\text { 17. I combine other methods with the } \\
\text { GTM in teaching English as a } \\
\text { foreign language. }\end{array}$ & 15 & $21.4 \%$ & 25 & $35.8 \%$ & 15 & $21.4 \%$ & 15 & $21.4 \%$ \\
\hline
\end{tabular}

Then, the last statement indicated how they utilized the GTM in the classroom, and whether they believed it was sufficient to employ this method alone or to combine this method with other methods to help the learning process in the classroom. The percentage findings from this statement were nearly balanced; as shown in Table $17,42.8 \%$ or 30 respondents believed that using the GTM alone can fulfill all learning requirements. Meanwhile, $57.2 \%$ or 40 respondents said they combined the GTM with other methods to improve the traditional method. More than half of the PET2017 preferred to combine this method with other methods after considering many aspects in the classroom to maximize each method used during the learning process, according to the percentage. See Table 4.

Despite being an old method, GTM was considered as a method that could be used to deal with the problems faced by PET2017 during the learning process in their teaching practicum. It was because the method was considered comfortable to use and made the learning process effective since the learning process became more efficient, based on respondent 7. This was compatible with Zulprianto's (2014) statement who stated that in 
Indonesian education, the GTM had never been ignored. He stated that it was because many Indonesian teachers were still struggling in teaching EFL since they were not native speakers. As a result, as long as the method facilitated a better learning process, this approach was still appropriate to be applied in Indonesia because it can be used at any time to get an efficient learning process.

According to a study conducted by Setiyadi (2020), GTM had several disadvantages, one of which was its inefficiency in the use of time, which was still lacking. However, in the learning process carried out by the PET2017 during their practice, it stated otherwise. Some of the respondents, respondents 4 and 11, argued that using the GTM would allow them to maximize their teaching time. They mentioned that many students, in their case, did not understand the explanation provided when the teacher utilized only English, causing them to frequently seek a re-explain of the material, and if the teacher continued to explain in a language that they did not understand, almost all students will stop paying attention to the teacher's lesson because they will believe that no matter how many times the material was explained, they will still be unable to comprehend the meaning of the explanation. This was considered ineffective since this situation also required a large amount of time during the teaching process. As a result, the GTM was valued to be more effective in the learning process conducted by the PET2017 during their internship since learning objectives can be achieved in a shorter length of time. Based on the findings, it can be concluded that including the mother tongue in learning activities had a major impact on students since this method made the learning process more efficient in time management.

There was one more disadvantage that cannot be ignored so that PET2017 must face this problem. The problem was that the implementation of the GTM was still teacher-centered because of the minimal interaction between students and teachers during the learning process (Khan \& Mansoor, 2016). Based on the Curriculum 2013, students were expected to be more active than teachers during the learning process since student-centered learning was required in Curriculum 2013. Even so, most of the PET2017 still chose this method after considering all aspects in the classroom. In addition, respondent 9 even stated that his teacher supervisor who was assisting him during their practicum also suggested this method even though this method was not a method that required lots of student activities.

To make this method compatible with the regulations set by the government in the Curriculum 2013, among the eleventh of respondents in interviews, eight respondents stated that they chose to combine the GTM with a variety of modern methods to make the learning process more effective. Then most of them, five respondents, chose Communicative Language Teaching (CLT) as the modern method since it was believed to be able to increase student involvement in the classroom. In line with PET2017's opinions in the interview, this study also suggests a combination of GTM and CLT because when these two methods were used together, student and teacher interactions occurred more frequently that made the learning process more interactive. This statement is compatible with a study from Na Kong (2011) who found that the GTM helped students to understand language rules and master the listening, reading, speaking, and writing skills in a better way. However, she stated that GTM needs to cover its shortcomings by combining it with the communicative method so that the interactions between teachers and students were not lacking. It showed that we did not always have to use only one method in teaching, we should combine several methods since we can cover the shortcomings of one method with other methods so that learning becomes more effective. 


\section{Conclusion}

Every study has limitations, and this research is no exception. Unfortunately, due to the difficulty of reaching the entire population during a pandemic, researchers were only able to acquire $60 \%$ of the total population of PET 2017 and the data collection can only be done online. Therefore, the researcher hopes that future studies with a larger sample size will be conducted in the future to acquire further information on the topic. Another limitation of this study is that the researchers only used primary data that she had personally collected because it is more accurate and current. Gathering all of the necessary data, on the other hand, takes a long time. As a result, the researcher hopes that future researchers will be able to cut down the data collection time by combining the two types of data, primary and secondary data.

Despite the limitations, based on the data analysis, it still can be concluded that the majority of pre-service English teachers batch 2017 (PET2017) showed a positive response to the GTM. The results of this research discovered that The GTM is proven to be a method that is still frequently used by PET2017 because it is still considered useful or effective to be employed in learning activities during their teaching internships or KPL programs. Students, according to the PET2017, also show great responses toward this method. Therefore, this method is considered to be an effective method to utilize since it helps to establish a comfortable learning environment because students become more responsive and relax since students understand better. The misunderstandings are also unlikely to happen because the teacher and students communicate in class using their mother tongue. The PET2017 also discovered that positive student responses contributed to improving students' English skills, especially their reading, vocabulary, and even writing skills because by utilizing the GTM, students were able to grasp the lesson better.

According to the data analysis, the GTM has a shortcoming that has to be addressed, namely the low amount of student engagement with the teacher during the learning process. To increase the student-teacher interactions in the classroom, most of the PET2017 decided to combine the implementation of the GTM with another approach, namely CLT, so that the lesson can be more student-centered and per Curriculum 2013 regulations. Therefore, this study suggests that GTM should be combined with modern methods that are aligned with the 2013 Curriculum to increase student activity, creativity, and critical thinking, as well as increase the challenges for teachers in the twenty-first century to make the learning process more effective. Of course, CLT can still be employed, but there is a recent and better method that teachers can utilize to meet the objectives of Curriculum 2013, namely the scientific learning approach. The scientific learning approach, according to Andariyani and Nurhajati (2016), is a method that requires students to be more active in the learning process by observing, developing problems, submitting hypotheses, collecting data, analyzing results, drawing conclusions, and expressing ideas in front of the class. This is, of course, an excellent way to solve GTM's shortcomings, which are mostly centered on student comprehension only.

\section{References}

Afiah, D. S. S. (2014). Improving students' reading ability using GTM. Journal of English Language and Learning, 2(1), 223-229. doi: 10.33603/perspective.v2i1.1624

Anabokay, Y. M., \& Suryasa, I. W. (2019). TEFL methods in Indonesia. International Journal of Linguistics, Literature, and Culture, 5(2), 13-24. doi: 10.21744/ijllc.v5n2.612 
Andariyani, N., \& Nurhajati, D. (2016). The implementation of teaching English based on Curriculum 2013 applied by an English teacher of junior high school. English Education: Journal of English and Research, 1(2), 9. doi: https://doi.org/10.29407/jetar.v1i2.480

Aqel, I. M. (2013). The effect of using grammar-translation method on acquiring English as a foreign language. International Journal of Asian Social Science, 3(12), 2469-2476. Retrieved from https://archive.aessweb.com/index.php/5007/article/view/2596

Arikunto, S. (2010). Prosedur penelitian: Suatu pendekatan praktek (edisi revisi V). Jakarta: Rineka Cipta.

Brown, H. D. (2015). Teaching by principles (4th ed.). New York: Pearson Education. Retrieved from https://pdfcoffee.com/2015-teaching-by-principles-by-h-douglas-brown-an-interactive-approach-tolanguage-pedagogy-4th-edition-pearson-education-esl-pdf-free.html\#20892+PDF

Chang, S. (2011). A contrastive study of GTM and communicative approach in teaching English grammar. Journal of English Language Teaching, 4(2), 13-24. doi: 10.5539/elt.v4n2p13

Creswell, J. W., \& Clark, V. L. P. (2018). Designing and conducting mixed method research (3 ${ }^{\text {rd }}$ ed.). Los Angeles: Sage Publications. Retrieved from http://pdfcoffee.com/qdownload/creswell-john-w-clark-vicki-lplano-designing-and-conducting-mixed-methods-research-sage-publications-2018pdf-pdf-free.html

Debata, P. K. (2013). The importance of grammar in English language teaching - A reassessment. Language in $\begin{array}{lllll}\text { India, } & 13 & \text { (5), } & 482-486 . & \text { Retrieved }\end{array}$ http://www.languageinindia.com/may2013/pradeepgrammarfinal.pdf

Eggleston, J. (1977). Making decisions in the classroom. Cambridge Journal of Education 7(1), 5-11. doi: https://doi.org/10.1080/0305764770070102

Elmayantie, C. (2015). The use of GTM in teaching English. Journal on English as a Foreign Language, 5(2), 125132. doi: https://doi.org/10.23971/jefl.v5i2.372

Guerra, A. F. (2014). The usefulness of translation in foreign language learning: Students' attitudes. International Journal of English Language and Translation Studies, 2(1), 153-170. Retrieved from https://www.researchgate.net/publication/261641087

Khan, A. B., \& Mansoor, H. S. (2016). The effectiveness of GTM in teaching and learning of English language at intermediate level. International Journal of Institutional \& Industrial Research, 1(1), 22-25. Retrieved from http://www.iiir.co.in/ijiir/vol1issue1/IJIIR-01-01-06

Kong, N. (2011). Establishing a comprehensive English teaching pattern combining the communicative teaching method and the grammar-translation method. Journal of English Language Teaching, 4(1). doi: $10.5539 /$ elt.v4n1p76

Kurniawan, R., Miftah, M. Z. \& Qamariyah, Z. (2020). Grammar-translation method affects students' reading comprehension and motivation. International Journal of Research on English Teaching and Applied Linguistics, 1(1), 7-15. Retrieved from https://www.jurnal.iainbone.ac.id/index.php/ijretal/article/view/1194

Liu, T. (2019). GTM can be optimized when associated with online English learning tools. International Conference on Education, Management, and Social Science, 3, 92-96. Retrieved from https://www.clausiuspress.com/conference/article/artId/1962.html

Mart, C. T. (2013). The grammar-translation method and the use of translation to facilitate learning in ESL classes. Journal of Advances in English Language Teaching, 1(4), 103-105. Retrieved from http://www.european-science.com/jaelt

Maru'ao, N. (2018). Developing students' ability in writing sentences in short paragraph through GTM at 11 grade of SMAN 1 Sirombu. Jurnal Ilmiah Dikdatik IKIP Gunungsitoli 12(2), 2152-2160. Retrieved from https://ojs.ikipgunungsitoli.ac.id/index.php/dk/article/view/17

Mijan, A. A. (2018). The efficaciousness of the grammar-translation method at undergrad level in Bangladesh. Bangladesh Research Foundation Journal, 7(2), 33-45. 
Ozfidan, B. (2017). Right of knowing and using mother tongue: A mixed method study. English Language Teaching, 10(12), 15-23. doi: 10.5539/elt.v10n12p15

Pan, Y-C. (2017). Teaching vocabulary to improve reading comprehension. Studies in Literature and Language, 15(4), 38-40. doi: http://dx.doi.org/10.3968/10013

Payne, M., \& Contreras, J. (2019). Ecudorian students' perception on the use of translation in the EFL classroom. Studies in English Language and Education, 6(1), 61-70. doi: https://doi.org/10.24815/siele.v6i1.12072

Penny Ur, (2013) Language-teaching method revisited, ELT Journal, 67(4), 468-474, dai: https://doi.org/10.1093/elt/cct041

Prastyo, H. (2015). The implementation of GTM (GTM) and communicative language teaching (CLT) in teaching integrated English. Indonesian EFL Journal, 1(2), 170-182. Retrieved from http://ejournal.kopertais4.or.id/index.php/efi

Resmini, S. (2019). EFL students' perception towards the use of bahasa Indonesia in an English classroom. Journal of English Language Teaching in Indonesia, 7(1), 12-22. doi: 10.22460/eltin.v7i1.p12-22

Richards, J. C., \& Rodgers, T. S. 2001. Approaches and methods in language teaching (2nd ed.). United Kingdom: Cambridge University Press. Retrieved from https://books.google.co.id/books?id=HrhkAwAAQBAJ\&printsec=copyright\#v=onepage\&q\&f=false

Setiyadi, B. (2020). Teaching English as a foreign language (2nd ed.). Yogyakarta: Graha Ilmu. Retrieved from http://repository.lppm.unila.ac.id/23179/

Silva, M. \& Cain, K. (2014). The relations between lower and higher level comprehension skills and their role in prediction of early reading comprehension. Journal of Educational Psycology, 107(2), 321-331. doi: https://doi.org/10.1037/a0037769

Siregar, R. (2018). Grammar based translation method in translation teaching. International Journal of English Language \& Translation Studies, 6(2), 148-154. Retrieved from: https://www.semanticscholar.org/paper/Grammar-Based-Translation-Method-in-Translation-PpSiregar

Slameto. (2010). Belajar dan faktor-faktor yang mempengaruhinya. Jakarta: Rineka Cipta. Retrieved from https://adoc.pub/slameto-belajar-dan-faktor-faktor-yang-mempengaruhinya-jakar.html

Sugiyono. (2016). Metode penelitian: Kuantitatif, kualitatif, dan R\&D (Cetakan ke-24). Bandung: PT Alfabet. Retrieved from: https://edoc.tips/download/sugiyono-metode-penelitian-kuantitatif-kualitatif-dan-rd.pdf

Suprijadi, D. (2014). Method to post-method pedagogy administered by a classroom teacher in the teaching of English. Jurnal Ilmiah STIKIP Siliwangi Bandung, 8(1), 40-61. Retrieved from http://ejournal.stkipsiliwangi.ac.id/index.php/didaktik/article/view/154/130

Syuhudi, A. R. (2016). Pemilihan metode pengajaran bahasa Arab yang efektif. Jurnal Intelegensia, 4(1), 62-75. Retrieved from https://ejournal.unisnu.ac.id/JI/article/view/1356

Zulprianto. (2012). Looking on the bright side of grammar-translation method. Indonesian Journal of English Language Teaching, 8(1). doi: https://doi.org/10.25170/ijelt.v8i2.1527 